\title{
TAFSIR AYAT AHKÂM GENDER (Kajian tentang Bagian Hak Waris dan Kepemimpinan Perempuan)
}

\author{
Neni Nuraeni \\ Fakultas Syariah dan Hukum UIN Sunan Gunung Djati Bandung \\ E-Mail: nuraieniabdul@gmail.com
}

\begin{abstract}
At the centuries ago, the tradition of the inheritance distribution was main provisions by their ancestors in which the children and women are prohibited from getting the inheritance. Even, a widow is part of the inheritance that allowed to be inherited and contributed themselves. This situation continued until Islam came and freed women from a variety of oppression. However, this did not completely solve the problem of differences between the rights of men and women. It means there are still some verses being debated, for example the verse which explains the distribution of inheritance and leadership. This paper attempts to discuss issues related to these two issues that are the inheritance and leadership.
\end{abstract}

\begin{abstract}
Abstrak
Pada masa jahiliyah, tradisi pembagian harta pusaka yang diwarisi oleh leluhur mereka terdapat suatu ketentuan utama bahwa anak-anak yang belum dewasa dan kaum perempuan dilarang mempusakai harta peninggalan ahli warisnya yang telah meninggal dunia. Bahkan menurut mereka janda perempuan dari orang yang meninggal merupakan harta peninggalan yang dapat dipusakakan dan dipusakai kepada dan oleh ahli waris yang meninggal. Keadaan ini terus berlangsung hingga hadirlah Islam yang membebaskan wanita dari berbagai penindasan. Namun, Terangkatnya derajat kaum perempuan dengan hadirnya Islam, tidak sepenuhnya meredam masalah perbedaan hak kaum lelaki dan kaum perempuan. Artinya, masih ada beberapa ayat yang menjadi polemik, diantaranya ialah mengenai pebagian waris dan ayat tentang kepemimpinan. Tulisan ini mencoba untuk membahas hal yang berkaitan dengan dua permasalahan tersebut, yaitu mengenai waris dan kepemimpinan.
\end{abstract}

Kata Kunci:

Gender, Hak Waris, Kepemimpinan Perempuan

\section{A. Pendahuluan}

Istilah Gender berbeda dengan jenis kelamin (sex). Gender adalah pembagian lelaki dengan perempuan yang dibentuk secara sosial maupun kultural. Istilah ini pertama digunakan oleh Ann Oakley dan didefinisikan sebagai: "Behavior differences between women and men that are socially constructed created by men and women themselves; therefore they are matter of culture". Sementara, jenis kelamin (sex) lebih merupakan jenis kelamin yang ditentukan secara biologis atau ketentuan Tuhan. ${ }^{1}$

Membicarakan kaum perempuan dan kedudukannya dalam kehidupan sosial tentulah menarik. Apalagi dalam masyarakat yang secara umum bersifat patrilineal (memuliakan kaum lelaki dalam semua aspek kehidupan). tanpa disadari, kita sendiri terjerumus dalam praktek tindakan penindasan terhadap kaum perempuan, baik secara lang-

${ }^{1}$ Mansour Faqih, Posisi Kaum Perempuan dalam Islam: Tinjauan dari Analisis Jender, dalam Mansoer Faqih dkk, Membincang Feminisme: Diskursus Gender Perspektif Islam (Surabaya: Risalah Gusti. 1996), hlm. 1-2. 
sung maupun tidak langsung dan baik berlangsung dengan kasar maupun halus.

Perlakuan diskriminatif atas perempuan ini sebenarnya sudah dimulai sebelum Islam datang. Bahkan, dalam struktur sosial budaya bangsa Arab masa itu, perempuan merupakan makhluk yang tidak berharga sehingga masyarakat Arab selalu memandangnya dengan sebelah mata. Mereka merasa hina dan merupakan aib jika memiliki anak perempuan, sehingga tidak jarang mereka mengubur hidup-hidup anak perempuannya atau jika sudah terlanjur hidup sampai usia dewasa, perempuan diperlakukan seperti harta atau barang yang bisa diwariskan, bukan yang menerima waris. Keadaan ini terus berlangsung hingga hadirlah Islam yang membebaskan wanita dari berbagai penindasan. Maka, merupakan izzah dan kemuliaan Islam, karena dia telah memuliakan perempuan dan menegaskan eksistensi kemanusiaannya serta kelayakannya untuk menerima taklîf (tugas) dan tanggung jawab, pembalasan dan berhak pula masuk surga. ${ }^{2}$

Islam menghargai perempuan sebagai manusia yang terhormat. Sebagaimana lakilaki, perempuan pun mempunyai hak-hak kemanusiaan karena berasal dari satu pohon, satu ayah dan ibu, yaitu Nabi Adam dan Siti Hawa, sebagaimana firman Allah SWT:

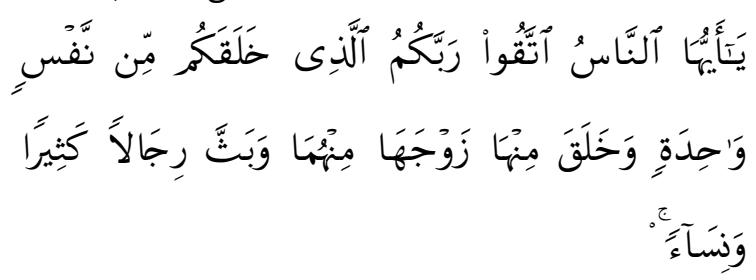

Hai sekalian manusia, bertakwalah kepada Tuhan-mu yang telah menciptakan kamu dari seorang diri, dan dari padanya Allah menciptakan isterinya; dan dari pada keduanya Allah memperkembang biakkan laki-laki dan perempuan yang banyak. (QS. Al-Nisâ:1)

Islam pun meletakkan perempuan dalam posisi yang seimbang. Perhatikanyatayat berikut:

${ }^{2}$ Yusûf al-Qardlawy, Anatomi Masyarakat Islam, terj. (Jakarta: Pustaka al-Kautsar. 1999), hlm. 293.
1. Al-Bâqarah : 187

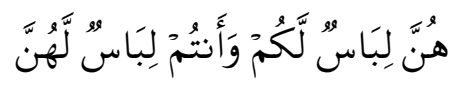

... Mereka adalah pakaian bagimu, dan kamu adalah pakaian bagi mereka...

2. Al-Nahl : 97

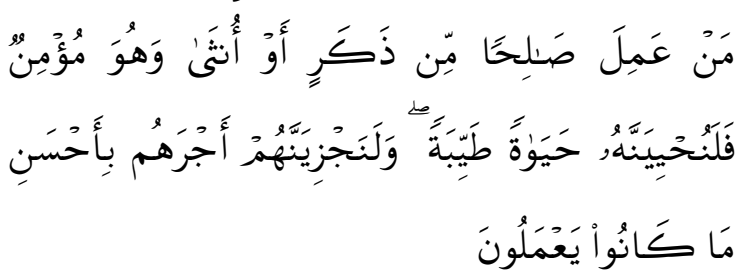

Barangsiapa yang mengerjakan amal shalih, baik laki-laki maupun perrempuan dalam keadaan beriman, maka sesungguhnya akan kami berikan kepadanya kehidupan yang baik dan akan kami balas mereka dengan pahala yang lebih baik dari apa yang mereka kerjakan.

3. QS. Al-Hujurât: 13

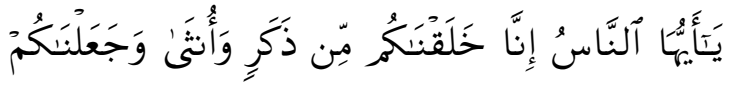

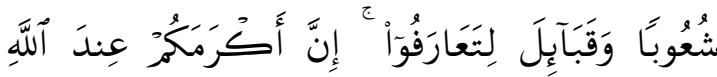

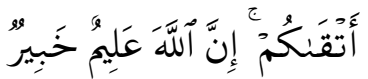

Hai manusia, Sesungguhnya Kami menciptakan kamu dari seorang laki-laki dan seorang perempuan dan menjadikan kamu berbangsa bangsa dan bersuku-suku supaya kamu saling kenal-mengenal. Sesungguhnya orang yang paling mulia diantara kamu disisi Allah ialah orang yang paling taqwa diantara kamu. Sesungguhnya Allah Maha mengetahui lagi Maha Mengenal.

Beberapa ayat tersebut menunjukkan bahwa Allah SWT telah memuliakan semua jenis manusia dengan nilai-nilai kemanusiaannya. Hanya satu hal yang membuat manusia lebih di hadapan Allah, yaitu ketakwaan.

Terangkatnya derajat kaum perempuan dengan hadirnya Islam, tidak sepenuhnya meredam masalah perbedaan hak kaum lelaki dan kaum perempuan. Artinya, masih ada beberapa ayat yang menjadi polemik, di antaranya: (1) ayat tentang perbedaan pembagian waris bagi laki-laki dan perempuan, dan 
(2) ayat tentang kepemimpinan. Dua masalah ini dipandang oleh sebagian kalangan sebagai ayat- ayat yang diskriminatif dan tidak memenuhi rasa “ keadilan". Oleh karena itu, untuk membatasi pembahasan, tulisan ini difokuskan untuk membahas polemik sekitar kedua hal tersebut.

\section{B. Dasar Hukum Pembagian Waris dalam Islam}

\section{Formulasi Pembagian Waris dalam al- Quran}

Dasar hukum waris dalam al-Quran tertuang dalam surat al-Nisâ ayat 7, 11, 12, 33, dan 176 sebagai berikut:

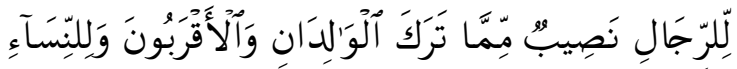

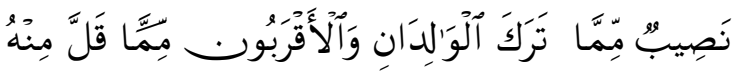

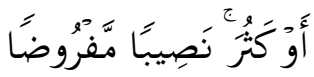

Bagi orang laki-laki ada hak bagian dari harta peninggalan ibu-bapa dan kerabatnya, dan bagi orang wanita ada hak bagian (pula) dari harta peninggalan ibu-bapak dan kerabatnya, baik sedikit atau banyak menurut bahagian yang telah ditetapkan. (al-Nisâ : 7)

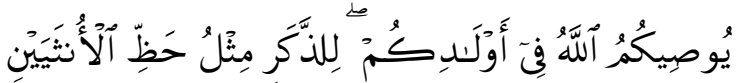

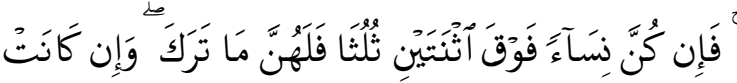

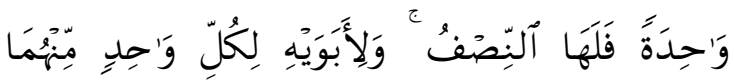

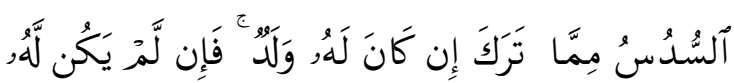

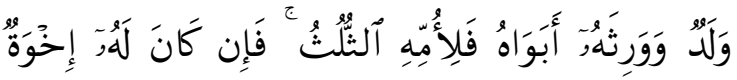

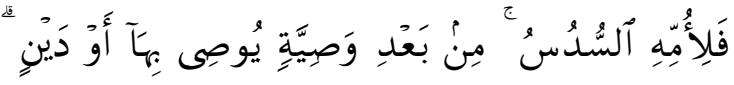

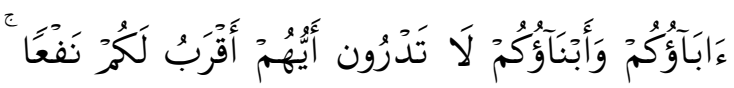

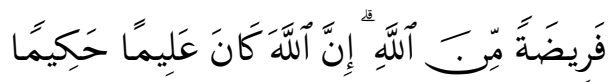

Allah mensyari'atkan bagimu tentang (pembagian pusaka untuk) anak-anakmu. Yaitu : bahagian seorang anak lelaki sama dengan bagahian dua orang anak perempuan; dan jika anak itu semuanya perempuan lebih dari dua, maka bagi mereka dua pertiga dari har- ta yang ditinggalkan; jika anak perempuan itu seorang saja, Maka ia memperoleh separo harta. dan untuk dua orang ibu-bapak, bagi masing-masingnya seperenam dari harta yang ditinggalkan, jika yang meninggal itu mempunyai anak; jika orang yang meninggal tidak mempunyai anak dan ia diwarisi oleh ibu bapaknya (saja), Maka ibunya mendapat sepertiga; jika yang meninggal itu mempunyai beberapa saudara, Maka ibunya mendapat seperenam. (Pembagian-pembagian tersebut di atas) sesudah dipenuhi wasiat yang ia buat atau (dan) sesudah dibayar hutangnya. (Tentang) orang tuamu dan anakanakmu, kamu tidak mengetahui siapa di antara mereka yang lebih dekat (banyak) manfaatnya bagimu. ini adalah ketetapan dari Allah. Sesungguhnya Allah Maha mengetahui lagi Maha Bijaksana. (Al-Nisâ : 11)

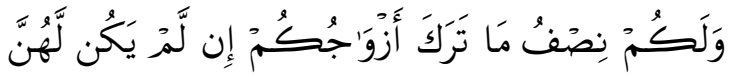

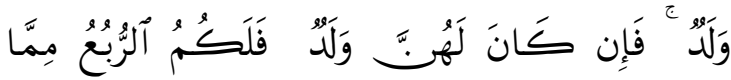

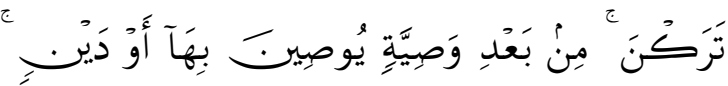

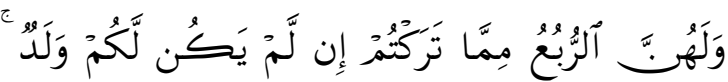

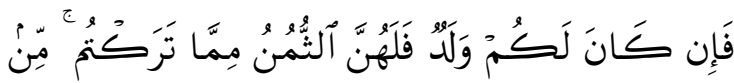

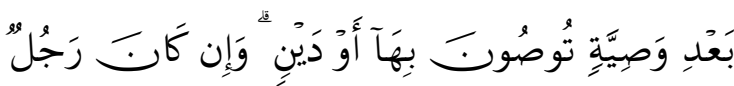

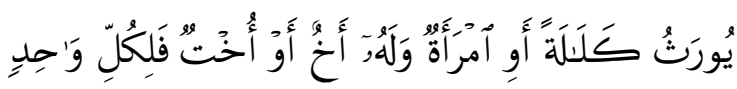

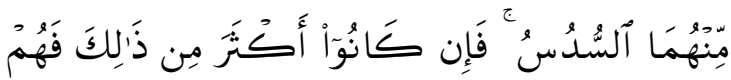

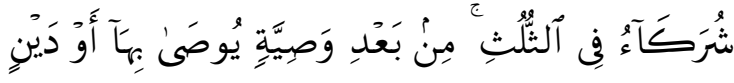

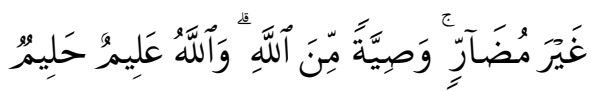

Dan bagimu (suami-suami) seperdua dari harta yang ditinggalkan oleh isteri-isterimu, jika mereka tidak mempunyai anak. jika isteriisterimu itu mempunyai anak, Maka kamu mendapat seperempat dari harta yang ditinggalkannya sesudah dipenuhi wasiat yang mereka buat atau (dan) seduah dibayar hutangnya. Para isteri memperoleh seperempat harta yang kamu tinggalkan jika kamu tidak mempunyai anak. jika kamu mempu- 
nyai anak, Maka Para isteri memperoleh seperdelapan dari harta yang kamu tinggalkan sesudah dipenuhi wasiat yang kamu buat atau (dan) sesudah dibayar hutanghutangmu. jika seseorang mati, baik laki-laki maupun perempuan yang tidak meninggalkan ayah dan tidak meninggalkan anak, tetapi mempunyai seorang saudara laki-laki (seibu saja) atau seorang saudara perempuan (seibu saja), Maka bagi masing-masing dari kedua jenis saudara itu seperenam harta. tetapi jika saudara-saudara seibu itu lebih dari seorang, maka mereka bersekutu dalam yang sepertiga itu, sesudah dipenuhi wasiat yang dibuat olehnya atau sesudah dibayar hutangnya dengan tidak memberi mudharat (kepada ahli waris). (Allah menetapkan yang demikian itu sebagai) syarî́at yang benarbenar dari Allah, dan Allah Maha mengetahui lagi Maha Penyantun. (Al-Nisâ: 12)

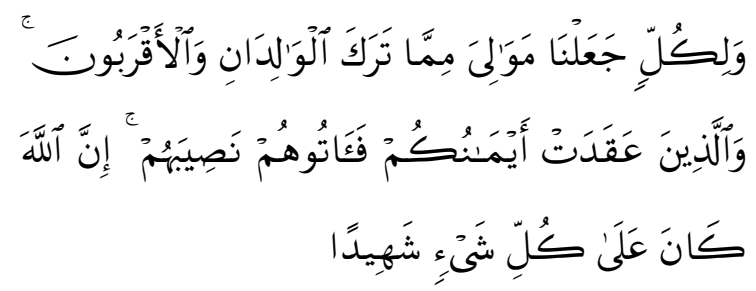

Dan bagi tiap-tiap harta peninggalan dari harta yang ditinggalkan ibu bapak dan karib kerabat, Kami jadikan pewaris-pewarisnya dan (jika ada) orang-orang yang kamu telah bersumpah setia dengan mereka, Maka berilah kepada mereka bahagiannya. Sesungguhnya Allah menyaksikan segala sesuatu. (Al-Nisâ: 33)

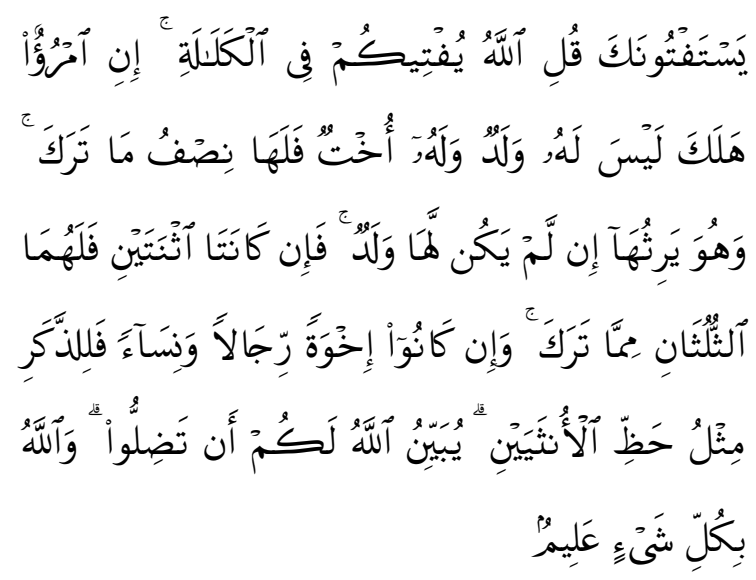

Mereka meminta fatwa kepadamu (tentang kalalah). Katakanlah: "Allah memberi fatwa kepadamu tentang kalalah (yaitu): jika seorang meninggal dunia, dan ia tidak mempunyai anak dan mempunyai saudara perempuan, Maka bagi saudaranya yang perempuan itu seperdua dari harta yang ditinggalkannya, dan saudaranya yang laki-laki mempusakai (seluruh harta saudara perempuan), jika ia tidak mempunyai anak; tetapi jika saudara perempuan itu dua orang, Maka bagi keduanya dua pertiga dari harta yang ditinggalkan oleh yang meninggal. dan jika mereka (ahli waris itu terdiri dari) saudara-saudara laki dan perempuan, Maka bahagian seorang saudara laki-laki sebanyak bahagian dua orang saudara perempuan. Allah menerangkan (hukum ini) kepadamu, supaya kamu tidak sesat. dan Allah Maha mengetahui segala sesuatu. ( Al-Nisâ: 176)

Asbâb al-nuzûl ayat- ayat tersebut adalah pada masa jahiliyah, dalam tradisi pembagian harta pusaka yang diwarisi oleh leluhur mereka terdapat suatu ketentuan utama bahwa anak-anak yang belum dewasa dan kaum perempuan dilarang mempusakai harta peninggalan ahli warisnya yang telah meninggal dunia. Tradisi menganggap bahwa anakanak yang belum dewasa dan kaum perempuan adalah sebagai keluarga yang belum dan tidak pantas menjadi ahli waris. ${ }^{3}$ Bahkan menurut mereka janda perempuan dari orang yang meninggal merupakan harta peninggalan yang dapat dipusakakan dan dipusakai kepada dan oleh ahli waris yang meninggal.

Pandangan ini bahkan masih diikuti oleh orang-orang yang telah masuk Islam sekalipun, sampai suatu saat ada yang mengadukan persoalan mereka kepada Rasulullah Saw. seperti yang dilakukan oleh janda Sa'ad ibnu al-Rabbi‘. Dia mengeluhkan kepada Rasulullah bahwa dua anak perempuan Sa'ad sama sekali tidak mendapatkan warisan dari harta peninggalan bapak mereka. Saudara laki-laki Sa'ad mengambil harta peninggalan Sa'ad tanpa tersisa sedikit pun untuk kedua anak perempuannya, padahal mereka sangat membutuhkan harta tersebut untuk biaya

\footnotetext{
${ }^{3}$ Muhammad Husayn al-Thabathaba'i, al-Mîzân fî tafsîr al-Qur'ân, hlm. 132.
} 
pernikahan. Pada saat itu Nabi berpesan kepadanya agar dia kembali sambil mengatakan bahwa Allah akan memutuskan masalah ini. Beberapa waktu kemudian dia datang lagi untuk mengeluhkan hal yang sama. Pada saat itulah ayat-ayat ini diturunkan. Nabi memerintahkan saudara Sa'ad memberikan 2/3 kekayaannya untuk anaknya dan $1 / 8$ kepada ibunya, dan dia mendapatkan sisanya. ${ }^{4}$

Dengan demikian, dilihat dari konteks ini menjadi jelas bahwa al-Quran menjamin perempuan mendapatkan haknya sebagai seorang anak, isteri dan ibu. Hanya saja, yang kemudian jadi persoalan adalah kasus pembagian warisan antara laki-laki dan perempuan yang tidak sebanding yang dipandang oleh sebagian kalangan tidak memenuhi rasa keadilan.

\section{Polemik Seputar Komposisi 1:2 (satu berbanding dua)}

Berdasarkan urat al-Nisâ Ayat 11 dan 176, yaitu terdapat penggalan kalimat:

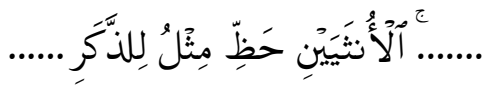

Ketentuan Kompoisi bagi anak laki-laki dua kali lipat bagian perempuan.

Di Negara kita, beberapa tahun lalu, telah terjadi diskusi yang cukup panas tentang pemaknaan ayat ini. Persoalannya berkisar pada apakah komposisi 1:2 (satu berbanding dua) ini merupakan kepastian hukum yang tidak bisa diganggu gugat, ataukah sangat fleksibel sesuai dengan ruang dan waktu.

Mahmud Thahâ, sebagaimana dikutip oleh Masdar F. Mas'udi, menyatakan bahwa semua ketentuan tentang waris bersifat kondisional. Ayat tersebut merupakan ayat Madaniyah. Dan yang Madaniyah itu kondisional, sehingga ketika menilainya kita juga harus mempertimbangkan konteks. Jangan sampai menilai suatu gagasan empat belas abad yang lalu dalam perspektif hari ini. Dengan mengatakan bagian warisan perempuan separo bagian laki-laki dalam perspektif hari ini, tawaran al-Quran tadi tidak radikal. Tapi dalam perspektif saat itu dinilai sangat

${ }^{4}$ Fakhruddin al-Râzi, Tafsîr al-Kabîr (Beirut: Dâr alfikr. t.th), jilid. V, hlm. 210. radikal, karena sebelumnya perempuan hanya bagian dari barang warisan. ${ }^{5}$ Kemudian Islam datang dan mengangkat perempuan dari objek menjadi subjek, meskipun belum full capacity. Mungkin karena caranya yang tadrîj (bertahap), sehingga tidak langsung seratus persen sebagaimana laki-laki. Ini sebenarnya baru langkah pertama. Suatu saat jika memungkinkan dan dikehendaki, perempuan bisa mendapatkan sama, bahkan lebih dari laki-laki. ${ }^{6}$

Munawir Sadzali (mantan Menteri Agama Rl) memiliki pendapat yang sama dengan pendapat sebelumnya. Menurutnya, pembagian 1:2 seharusnya direaktualisasikan dan disesuaikan dengan perkembangan ruang dan waktu. Ide yang dilontarkannya ini bertujuan agar dalam pembagian waris umat Islam di Indonesia memberikan bagian yang sama terhadap anak laki-laki dan perempuan. Alasan yang dipegangnya adalah dahulu pada masa sebelum Islam wanita sama sekali tidak mendapat bagian warisan. Setelah Islam datang, wanita diberi bagian warisan meskipun hanya setengah dari bagian laki-laki. Ini berarti secara sadar Islam hendak meningkatkan hak dan derajat wanita. Alasan kenapa tidak sekaligus saja wanita diberi bagian yang sama dengan laki-laki memang tidak jelas, tetapi ajaran Islam itu memang diberlakukan secara bertahap (ingat penetapan pengharaman khamr). Karena itu dapat dipahami bahwa jiwa dari ayat waris tersebut ialah bahwa pada dasarnya usaha meningkatkan hak dan derajat wanita itu harus terus dilakukan dan tidak boleh berhenti. Kemudian oleh karena kehidupan modern sekarang ini telah memberikan kewajiban yang lebih besar kepada wanita dibanding pada masa lalu sehingga wanita kini juga dapat memberikan peran yang sama dengan laki-laki dalam masyarakat, maka logis saja kalau hak-haknya dalam warisan juga ditingkatkan agar sama dengan laki-laki.?

${ }^{5}$ Lily Zakiah Munir, Ed., Memposisikan Kodrat Perempuan dan Perubahan dalam Perspektif Islam (Bandung: Mizan 1999), hlm. 24.

${ }^{6}$ Ibid, hlm. 24.

${ }^{7}$ Satria Efendi M. Zein," Munawir Sadzali dan Reaktualisasi Hukum Islam" dalam Munawir Sadzali, 


\section{Argumentasi atas Komposisi Kaum Pe- rempuan Mendapat Hanya Setengah dari Komposisi Kaum laki-Laki}

Pertama, ayat ini sebenarnya merupakan respons terhadap kondisi sosial yang berkembang saat itu. Sebagaimana diketahui, perempuan masa itu tidak mempunyai hak untuk memiliki apa pun yang diberikan kepadanya. Secara historis-sosiologis, ayat ini sebenarnya bentuk penyadaran kemanusiaan bahwa perempuan, sebagaimana lakilaki, mempunyai hak untuk mempunyai harta, baik melalui warisan, mas kawin, nafkah dan wasiat. Dengan pemahaman seperti ini, berarti realitas 2:1 sebenarnya adalah cerminan realitas historis-sosiologis yang sangat bergantung pada ruang dan waktu. ${ }^{8}$

Kedua, secara teologis, bagian warisan laki-laki dilebihkan dari bagian perempuan, karena Islam membebani laki-laki dengan tanggung jawab dan kewajiban memberi mas kawin bagi isteri dan nafkah bagi keluarga. Sementara perempuan tidak memiliki kewajiban tersebut. Bahkan mereka akan menerima maskawin dan nafkah dari suaminya. ${ }^{9}$

Dua alasan di atas cukup logis untuk menjelaskan bahwa laki-laki memperoleh bagian yang lebih dibandingkan perempuan.

\section{Kepemimpinan Perempuan}

Berkaitan dengan kepemimpinan, para ulama sepakat tidak memperkenankan perempuan memegang tampuk kekhilafahan atau kepemimpinan dalam konteks umum yang biasa disebut sebagai al-wilayah al-'ammah atau al-imamah al-kubrâ atau al-imamah al-'uzhmâ yang representasinya adalah khalifah atau Rais daulah Islamiyyah. Alasannya, karena pada umumnya perempuan tidak memiliki potensi untuk "bertarung" dalam urusan politik yang rumit sebesar ini, padahal hal itu menjadi bagian yang tidak terpisahkan

Kontekstualisasi Hukum Islam (Jakarta: Paramadina. 1995), hlm. 312-313.

${ }^{8}$ Zaitunah Subhan, Tafsir Kebencian: studi bias gender dalam Tafsi al-Quran (Yogyakarta: LkiS. 1999), hlm. 128.

${ }^{9}$ Asghar Ali Engineer, Hak-Hak Perempuan dalam Islam (Yogyakarta: LSPPA. 2000), hlm. 109; Quran Surat Al-nisâ: 34 dan ayat 4. dalam dinamika perpolitikan. ${ }^{10}$ Kalaupun ada satu atau dua orang perempuan yang memiliki kemampuan lebih besar daripada lakilaki dalam urusan ini, seperti Ratu Saba yang dikisahkan dalam al-Quran surat al-Naml, namun hukum tidak dibangun di atas kekecualian, sebagaimana kaidah al-nâdzir lâ hukma lahû (sesuatu yang langka tidak bisa menjadi landasan hukum). ${ }^{11}$

Namun demikian, ada masalah lain yang masih menjadi bahan perdebatan, yaitu kaitannya dengan beberapa jabatan politik perempuan seperti presiden atau perdana menteri. Berikut ini dikemukakan dua pendapat dari ulama yang melarang perempuan menjadi pemimpin politik sebagai presiden dan ulama yang yang membolehkannya:

1. Pendapat yang Melarang Perempuan Menjadi Pemimpin Negara (Presiden)

Syeikh Taqiyyuddîn Al-Nabani dalam

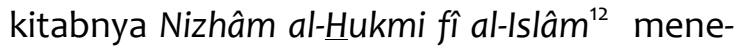
gaskan syarat-syarat utama seorang kepala negara, yaitu :

a. Muslim (Al-Nisâ : 141 dan Al-Nisâ :59);

b. Laki-laki, berdasarkan hadits: "Tidak akan pernah beruntung suatu kaum yang menyerahkan urusannya kepada wanita" (HR Bukhâri dari Abû Bakrah);

c. Baligh, berdasarkan hadits: "Telah diangkat pena (tidak dibebankan hukum) dari orang yang tidur hingga ia bangun, anak-anak hingga ia baligh dan orang gila hingga akalnya kembali sehat" (HR Tirmidzî, Abû Dawud, Ahmad);

d. Berakal sehat, berdasarkan hadits di atas.-;

e. Adil, artinya konsisten dalam menjalankan agamanya. (Al-thalâq: 02) "Hendaklah menyaksikan dua orang yang adil (tidak fasik) di antara kalian". Kalau untuk saksi saja disyaratkan adil, maka terlebih lagi bagi khalifah;

\footnotetext{
${ }^{10}$ Cahyadi Takarariawan dkk, Keakhwatan 2 (Solo: Era Intermedia. 2005), hlm. 217.

${ }^{11} Y u s u ̂ f$ Al-Qardlawy, Anatomi Masyarakat. hlm. 299.

${ }^{12}$ Syekh Taqiyyuddîn Al-Nabhani, Nizham al-Hukmi fî al-Islâm (Libanon: Dâr al-Ummah. t.th), cet. IV, hlm. 48-51.
} 
f. Merdeka, karena seorang budak tidak memiliki wewenang untuk mengatur dirinya apalagi mengatur orang lain.

Jumhur ulama memiliki pendapat yang sama dengan mengatakan bahwa syarat pemimpin politik, yaitu:
a. Muslim
b. Merdeka
c. Baligh (dewasa)
d. Laki- laki. ${ }^{13}$

Dengan demikian syarat laki-laki sebagai kepala negara dan pejabat penguasa di bawahnya bukan wacana baru dalam Islam. Bahkan jumhur menyebut hal ini sebagai syarat mutlak bagi pemerintahan Islam. Hal ini telah menjadi sunnah Rasulullah dan ijma sahabat ra yang dipegang teguh oleh kaum muslimin dari masa ke masa. ${ }^{14}$

Pendapat Para ulama ini berpegang kepada dalil dalil berikut:

a. Al-Nisâ: 34, Allah SWT berfirman:

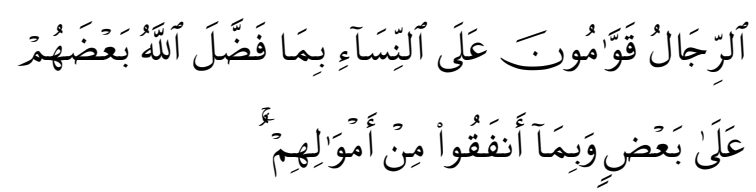

Para lelaki adalah pemimpin atas kaum perempuan, oleh karena Allah telah melebihkan sebahagian mereka (laki-laki) atas sebahagian yang lain (perempuan), dank arena mereka telah menafkahkan sebagian dari harta mereka.

Kata qawwâm pada ayat tersebut memiliki beberapa arti: penjagaan (hifzh) dan pemimpin. ${ }^{15}$ Dalam kamus bahasa Arab qawwâmûn diterjemahkan menjadi berdiri bersama, tiang, penopang, pihak yang bertang-

${ }^{13}$ Jaih Mubarak, Pemikiran al-Thahtawi tentang ljtihad dan Perwujudannya dalam Figh (Desertasi) Jakarta: Program Pasca Sarjana IAIN Syarif Hidayatullah. 1998), hlm. 134.

${ }^{14}$ Imam Ibnu Hazm, Marâtib al-ljma', halaman 162 dalam Najmah Sa'îdah dan Husnul Khotimah, Ibidem., dan Imam Al-Suyûthi, Tarîkh Khulafâ' (Terj.) (Jakarta Timur: Pustaka Al-Kautsar. 2001), hlm. 196.

${ }^{15}$ Muhammad 'Ali al-Shabuni, Rawâ'id al-Bayân: Tafsîr Âyât al-Ahkâm min al-Qur'ân (Beirut: Dâr al-Fikr, t. th.), hlm. 463. gung jawab, yang menanggung, amir, kepala, dan pemimpin. ${ }^{16}$

Sabab al-nuzûl ayat tersebut adalah seorang perempuan (yang sedang nusyûz) mengadu kepada Rasulullah bahwa suaminya telah menamparnya. Rasulullah saw. Bersabda bahwa suaminya akan dikenakan hukum qishash (balasan yang seimbang). Maka turunlah ayat ini (al-Nisâ:34). Sekembalinya ke rumah ternyata suaminya tidak mendapatkan hukuman tersebut, karena qishash tidak dapat diberlakukan sebab isteri di bawah tanggung jawab suaminya. ${ }^{17}$

Ayat ini memang berbicara tentang kepemimpinan laki-laki dalam rumah tangga, lalu hubungannya dengan negara adalah dapat diberlakukan qiyash awlâwi. Artinya bila pemimpin rumah tangga saja harus laki-laki, apalagi 'rumah tangga besar' (negara) lebihlebih lagi. Dengan kata lain, bila untuk mengatur urusan yang lebih kecil seperti urusan rumah tangga, Allah menetapkan laki-laki sebagai pemimpin atas perempuan, maka terlebih lagi masalah negara yang lebih besar dan kompleks tentu lebih wajib diserahkan kepada laki-laki.

b. Al-Nisâ : 59, Allah SWT berfirman:

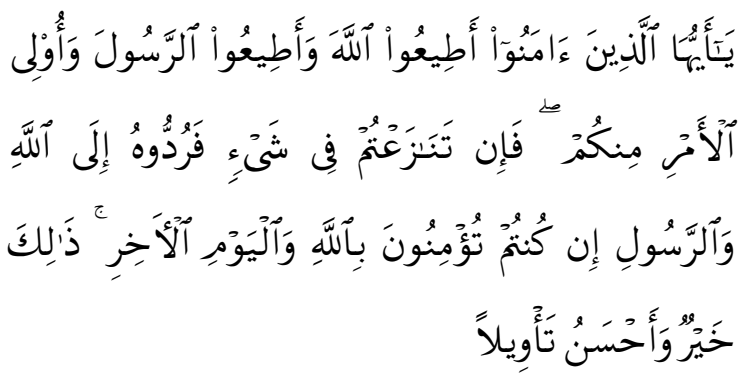

Hai orang-orang yang beriman taatilah Allah dan taatilah Rasul-Nya dan ulil amri di antara kalian. Kemudian jika kamu berlainan pendapat tentang sesuatu maka kembalikanlah kepada Allah dan Rasul-Nya.

Dalam ayat ini perintah taat kepada pemimpin menggunakan lafazh ulil amri. Berdasarkan kaidah bahasa Arab, maka bisa di-

\footnotetext{
${ }^{16}$ Ahmad Warson Munawwir, Kamus ArabIndonesia (Surabaya: Pustaka Progressif. 1997), hlm. 1174.

${ }^{17}$ Muhamad 'Ali Al-Shâbûnî, Mukhtashar Tafsîr ibnu Katsîr (Kairo: Dâr al- Shâbûnî. t.th), hlm. 385.
} 
mengerti bahwa perintah kepada pemimpin yang dimaksud dalam ayat tadi adalah pemimpin laki-laki. Sebab bila pemimpin yang dimaksud adalah perempuan, seharusnya digunakan kata ulâtu al-amri.

c. Hadits Nabi saw. yang artinya :

Suatu kaum tidak akan pernah beruntung apabila kepemimpinan diserahkan kepada perempuan. (HR. Al-Bukhârî) ${ }^{18}$

Berkaitan dengan larangan ini, tidak berarti melarang perempuan terlibat dalam segala aspek perpolitikan. Ada bidang- bidang yang perempuan boleh bahkan harus terlibat di dalamnya, antara lain: (a) Hak dan Kewajiban Baiat berdasarkan hadits yang diriwayatkan oleh Ummu Athiyyah ra bahwa "Kami telah membaiat Nabi. Beliau kemudian memerintahkan kepada kami untuk tidak menyekutukan Allah dengan sesuatupun dan melarang kami untuk melakukan niyahah ..."(HR. Bukhâri). (b) Hak memilih dan dipilih menjadi anggota majelis ummah, yaitu suatu badan di dalam negara Islam yang terdiri dari wakilwakil rakyat yang bertugas memberi nasihat dan pendapat ummat kepada negara. Hal ini didasarkan pada apa yang terjadi pada pasca peristiwa baiat Aqabah II, dimana Rasulullah meminta 12 orang dari ke-75 orang pelaku baiat yang 2 orang di antaranya adalah wanita untuk menjadi penjamin atas berbagai tanggungan mereka. (c) Kewajiban berdakwah dan amar ma'rûf nahî al-munkar sebagaimana tertera pada surat Ali 'Imrân:104 dan surat al-Tawbah: 71. (d) Kewajiban menasehati dan mengoreksi penguasa, berdasarkan hadits: "Agama itu nasehat." Kami bertanya, "bagi siapa?" Beliau bersabda :"bagi Allah, Rasul-Nya, para pemimpin dan kaum muslimin".(HR. Muslim)

\section{Pendapat yang Membolehkan Perem- puan Menjadi Pemimpin Negara}

Al-Mawardi berpendapat bahwa syaratsyarat pemimpin politik adalah:

a. Adil;

b. Berilmu sehingga mampu berijtihad;

c. Sempurna panca indera;

d. Sempurna anggota badan;

\footnotetext{
${ }^{18}$ Al-Bukhâri, Shahih al-Bukhâri, hlm. 97.
}
e. Cerdik;
f. Berani;
g. Berasal dari kalangan Quraysy. ${ }^{19}$

Sedangkan dalam hal ini Ibnu Sina berpendapat bahwa syarat-syarat pemimpin politik adalah:

a. Memiliki keberanian;

b. Adil;

c. Memiliki ilmu pengetahuan yang bagus; dan

d. Mengetahui hukum syara'. ${ }^{20}$

Pendapat di atas tidak menentukan lakilaki sebagai syarat pemimpin politik. Oleh karena itu, perempuan boleh menjadi pemimpin politik, termasuk menjadi presiden atau kepala neagara. Alasannya adalah presiden hanyalah pemimpin pemerintahan dan bukan pemimpin spiritual. Selain itu, presiden hanyalah pemegang kekuasaan eksekutif dalam system trias politika. Ini menunjukkan presiden bukanlah wilayah kepemimpinan umum (al-wilayah al-'ammah).

\section{Tadabbur}

Bagi sebagian kalangan, perbedaan pembagian waris lak-laki dan perempuan, juga hukum keharaman perempuan menjadi kepala negara atau pemegang kekuasaan seringkali dianggap sebagai bentuk diskriminasi syari'at atas perempuan. Kalangan feminis bahkan menjadikan fakta-fakta hukum seperti ini sebagai penguat konklusi, bahwa Islam menganut ajaran misoginis dan budaya patriarkis yang selama ini dianggap sebagai penyebab terjadinya ketidakadilan sistemik atas perempuan.

Untuk menjawab tudingan tersebut, tidak sedikit kalangan intelektual muslim yang (secara apologetik) akhirnya intens menyerukan gagasan reinterpretasi atas nash syariat. Mereka berdalih, bahwa kesimpulan hukum seperti itu hanyalah persoalan interpretasi. Karenanya, muncul pendekatanpendekatan baru dalam memahami syari'at,

\footnotetext{
${ }^{19} \mathrm{Al}-$ Mawardi, al-Akam al-Sulthaniyah, (Beirut: Dâr al-Fikr. t.th), hlm. 6 .

${ }^{20}$ Muhamad 'Azîz Nazhmi Sâlim, al-Fikr al-Siyâsî wa al-Hukmi fi al-Islâm, (Iskandariah: Muassasah Syubab al-Hami'ah. t.th), hlm. 153.
} 
seperti heurmenetika, sosio-historis, dan sebagainya. Akibatnya, berbagai persoalan yang kedudukan hukumnya sebenarnya sudah jelas dan tidak ada pertentangan pendapat di kalangan ulama salaf dipertanyakan kembali hanya karena dianggap bertentangan dengan 'persepsi kekinian' tentang kesetaraan (gender).

Masalah perbedaan waris perempuan dan laki-laki, juga keharaman perempuan sebagai pemimpin negara, seharusnya semata dipandang sebagai hukum syari'at yang keberadaannya secara keseluruhan berfungsi sebagai solusi atas problematika kehidupan manusia. Oleh karena itu, sebaiknya kita memiliki sikap sebagai beikut:

1. Senantiasa Husnu al-Zhan kepada Allah dan Mencari Hikmah Dibalik Semua Kejadian

Sebagaimana diketahui, keberadaan syari'at hakekatnya ditujukan untuk menjamin tercapainya tujuan-tujuan luhur masyarakat manusia yang terdiri atas laki-laki dan perempuan, tanpa kecuali. Adanya persamaan taklif hukum maupun pembedaan taklif atas laki-laki dan perempuan yang ada dalam syari'at sesungguhnya harus dipahami dalam kerangka tujuan itu, bukan dalam rangka mendiskriminasi kaum perempuan. Terlebih Islam memandang kemuliaan hakiki manusia bukan karena jenis peran yang ditaklifkan kepadanya, melainkan dilihat dari tanggungjawab dan pelaksanaan atas peran yang ditaklifkan Allah kepadanya yang disebut dengan ketakwaan (Lihat surat al-Hujûrat: 13). Disinilah Islam memberikan kesetaraan hakiki pada manusia secara keseluruhan, baik atas laki-laki maupun perempuan.

\section{Meyakini Allah sebagai Pengatur ter-} baik.

Sebagai dîn yang sempurna, Islam tegak di atas keyakinan bahwa Allah SWT adalah Pencipta dan sekaligus sebagai Pengatur Kehidupan. Oleh karenanya, dari aspek syari'at bagi pengaturan kehidupan, termasuk tentang relasi perempuan dan laki-laki serta bagaimana pembagian peran dan fungsi di antara keduanya, Islam dipastikan memiliki konsep yang ideal, lurus dan komprehensif, karena Islam berasal dari Dzat Yang Maha Pen- cipta, Maha Sempurna, Maha Tahu dan Maha Adil. Dan hal ini terbukti dari fakta keberadaan masyarakat Islam yang senantiasa muncul sebagai masyarakat ideal dan gemilang, dimana salah satunya, perempuan mendapat tempat yang sempurna dan selayaknya. Banyak bukti sejarah yang menunjukkan bagaimana kiprah kaum perempuan, termasuk kiprah politik mereka di masa keemasan Islam yang membuktikan terjaminnya kesetaraan hakiki yang diberikan Islam atas mereka.

\section{Berlapang Dada dengan Ketentuan Allah}

Pada faktanya, Islam memang adakalanya menetapkan hukum yang sama kepada laki-laki dan perempuan jika hal tersebut terkait dengan sisi insaniyah keduanya yang memiliki potensi akal dan potensi kehidupan yang sama. Dalam hal ini, Islam menetapkan kewajiban shalat, shaum, menuntut ilmu, birrul walidayn, berakhlak mulia, berdakwah dan lain-lain baik kepada laki-laki maupun perempuan tanpa membedakan keduanya. Akan tetapi Islam kadangkala juga menetapkan hukum yang berbeda jika hal tersebut terkait dengan sisi jinsiyah keduanya yang memang faktanya diciptakan secara berbeda. Karenanya Islam menetapkan peran utama perempuan sebagai ibu dan pengatur rumahtangga, sementara laki-laki diberi tanggungjawab sebagai pemimpin dan pencari nafkah, termasuk memimpin negara. Pembagian peran ini adalah semata-mata demi kebaikan manusia secara keseluruhan agar kebahagiaan hakiki bisa mereka raih secara bersama. Inilah kenapa Allah SWT mewanti-wanti manusia agar tidak saling iri hati atas apa yang sudah ditetapkan Allah sebagai Pencipta kehidupan, Yang Maha Adil, Maha Tahu dan Maha Sempurna. Firman Allah SWT:

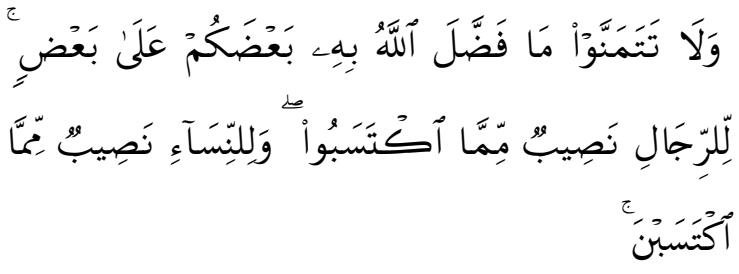


Dan janganlah kamu iri hati dengan apa yang dikaruniakan Allah kepada sebagian kamu lebih banyak dari sebagian yang lain (karena) bagi laki-laki ada bagian yang mereka usahakan dan bagi wanita (pun) ada bagian dari apa yang mereka usahakan. (An Nisâ :32)

\section{E. Penutup}

Islam datang menyelamatkan manusia, khususnya perempuan dari ketertindasan. Islam mengangkat harkat derajatnya yang sedang terpuruk dengan menempatkannya di tempat yang mulia. Bahkan, Islam menetapkan bahwa perempuan dan laki-laki sama-sama berhak mewarisi harta peninggalan kedua orang tua dan karib kerabat mereka masing-masing. Persoalan kemudian, laki-laki memperoleh dua kali lipat bagian perempuan, hendaknya difahami melalui pendekatan historis sosiologis dan pendekatan teologis.

Secara historis-sosiologis, ayat-ayat waris merupakan bentuk penyadaran kemanusian bahwa perempuan sebagaimana lakilaki, memiliki hak untuk mempunyai harta, baik melalui warisan, wasiat, mas kawin, dan nafkah. Secara teologis (tuntutan syari'at) laki-laki memiliki tanggung jawab memberi mas kawin dan nafkah, sementara perempuan tidak.

Mengenai kepemimpinan perempuan dalam politik, khususnya sebagai kepala $\mathrm{Ne}$ gara, terdapat dua pendapat. Ada ulama yang melarang secara tegas dengan mencantumkan laki-laki sebagai salah satu syaratnya. Tapi, ada pula ulama yang membolehkannya. Pendapat yang melarang melandasi pandangannya di antaranya dengan menggunakan qiyas aulawy bahwa jika dalam urusan rumah tangga saja laki-laki yang harus memimpin, apalagi dalam urusan yang lebih besar seperti Negara. Sementara pendapat yang membolehkan mendasari pandangannya dengan membedakan antara pemimpin Negara atau presiden dengan khalifah. Presiden hanyalah pemimpin pemerintahan dan bukan pemimpin spiritual. Selain itu, presiden hanyalah pemegang kekuasaan eksekutif dalam system trias politika. Ini menunjukkan presiden bukanlah wilayah kepemimpinan umum (al-wi- lâyah al-'ammah). Wallâhu A'lam bi al-Shawâb.

\section{Daftar Pustaka}

Engineer, Asghar Ali. 2000. Hak-Hak Perempuan dalam Islam. Yogyakarta: LSPPA.

Faqih, Mansour. 1996. Posisi Kaum Perempuan dalam Islam: Tinjauan dari Analisis Jender, dalam Mansoer Faqih dkk, Membincang Feminisme:Diskursus Gender Perspektif Islam. Surabaya: Risalah Gusti.

Mâwardli, al-. t.th. al-Ahkâm al-Sulthâniyyah. Beyrut: Dâr al-Fikr.

Mubarak, Jaih. 1998. Pemikiran al-Thahtawi tentang ljtihad dan Perwujudannya dalam Figh (Desertasi). Jakarta: Program Pasca Sarjana IAIN Syarif Hidayatullah.

Munawwir, Ahmad Warson. 1997. Kamus Arab-Indonesia. Surabaya: Pustaka Progressif.

Munir, Lily Zakiah. 1999. Memposisikan Kodrat Perempuan dan Perubahan dalam Perspektif Islam. Bandung: Mizan.

Nabhani, Taqiyyuddîn, An-. t.th. Nizham alHukmi fî al-Islâm. Beirut: Dâr al-Ummah.

Qardlawy, Yusuf, Al-. 1999. Anatomi Masyarakat Islam (terj). Jakarta: Pustaka alKautsar.

Razi, Fakhruddin, al-. t.th. Tafsir al-Kabî. Beyrut: Dâr al-fikr.

Salim, Muhamad 'Azîz Nazhmi. al-Fikr alSiyâsî wa al-Hukmi fi al-Islam. Iskandariah: Muassasah Syubab al-Hami'ah.

Shâbuni, Muhammad 'Alî, Al-. t.th. Rawâ'id alBayân: Tafsîr Âyât al-Ahkâm min al-Qur'ân. Beirut: Dâr al-Fikr. . t.th. Mukhtashar Tafsîr ibnu Katsîr. Kairo: Dar al- Shâbûnî.

Subhan, Zaitunah. 1999. Tafsir Kebencian: studi bias gender dalam Tafsi al-Quran, Yogyakarta: LkiS.

Suyûthi, Imam, Al-. 2001. Tarîkh Khulafâ' (terj.). Jakarta Timur: Pustaka Al-Kautsar.

Zein, Satria Efendi M. 1995. "Munawir Sadzali dan Reaktualisasi Hukum Islam" dalam Munawir Sadzali, Kontekstualisasi Hukum Islam. Jakarta: Paramadina. 